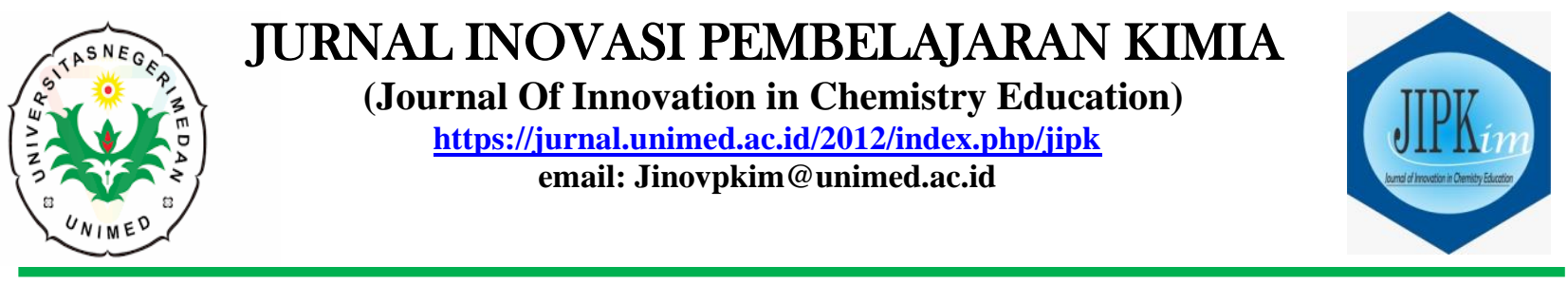

\title{
Pengaruh Model Pembelajaran Kooperatif Team Games Tournament (TGT) Berbantuan Media Teka-Teki Silang (TTS) Terhadap Hasil Belajar Dan Motivasi Siswa Pada Materi Tata Nama Senyawa Di Kelas X SMA Swasta Parulian 1 Medan
}

\author{
Agus Martinus Waruwu ${ }^{a, *}$, Nora Susanti $^{\mathrm{a}}$ \\ ${ }^{a}$ Program Studi Pendidikan Kimia, Universitas Negeri Medan, Medan \\ Alamat Korespondensi: agusmartinusw@gmail.com
}

\begin{abstract}
:
This study aims to determine student learning outcomes with the cooperative learning model TGT assisted by crossword puzzles on compound nomenclature material. Learning outcomes data collection tool used objective tests totaling 20 questions that have been tested for validity, difficulty level, different power, and reliability with an $r$ value of 0.92 . The results of data analysis showed an increase in student learning outcomes in the experimental class by $81.66 \%$ higher when compared to the control class by $75 \%$. The average value of learning outcomes in the experimental class was $81.66 \pm 9.17$, while the average value of student learning outcomes in the control class was $75 \pm 8.88$. The results of the one-tailed t test were obtained tcount $>$ t table (3.29> 1.67) so that Ha was accepted. This means that the learning outcomes of students in the experimental class are higher than those of the control class. The sum of students' motivation in the experimental class is initial motivation of 86.8, while final motivation is 96. This shows that the Team Games Tournament (TGT) cooperative learning model assisted by crossword media can improve learning outcomes and student motivation, and make a positive contribution to learning outcomes.
\end{abstract}

Key Words:

Team Games Tournament (TGT), Crosswords, Motivation, Nomenclature Compounds, and Learning Outcomes

\section{PENDAHULUAN}

Proses pembelajaran dalam pendidikan sangat ditekankan demi mewujudkan suatu tujuan pembelajaran terutama peningkatan sumber daya manusia yang berkreativitas tinggi. Pendidikan merupakan suatu usaha yang direncanakan untuk mewujudkan suasana belajar siswa dan proses belajar siswa yang dapat ditingkatkan dengan potensinya sendiri untuk menggali kemampuan yang dimilikinya. Siswa dapat mengembangkan kemampuannya selama mengikuti pembelajaran yang diberikan oleh guru dan dapat mencermati dari setiap langkah-langkah pembelajaran untuk dapat memahami akan materi yang dipelajari. Pelaksananya mengukur masukan (input), proses, dan keluaran (output) pembelajaran.

Tujuan pendidikan adalah untuk mengembangkan potensi siswa dalam domain kognitif, afektif, dan psikomotorik. Untuk mengembangkan level kompetensi yang 

Siswa Pada Materi Tata Nama Senyawa di SMA Swasta Parulian 1

berbeda (baik dalam domain kognitif, afektif, maupun psikomotorik) diperlukan metode mengajar yang berbeda. Meskipun sejumlah besar bukti penelitian menyoroti hasil yang signifikan dari penggabungan TGT kooperatif dalam probabilitas, penggunaannya dalam proses belajar mengajar tampaknya terbatas. Kebutuhan yang jelas untuk meninjau kembali pengajaran dan pembelajaran probabilitas telah menghasilkan dalam penelitian ini, yaitu untuk menggabungkan TGT dalam pengajaran dan pembelajaran, khususnya pada masalah sikap terhadap probabilitas belajar (Veloo,A. 2013).

(Ahmad \& Mahmood,2010) Strategi pembelajaran kooperatif dimana siswa bekerja aktif dalam kelompok untuk meningkatkan diri sendiri dan teman belajar dalam kelompok. (Soebagio,2000) Menyatakan bahwa model pembelajaran kooperatif tipe TGT merupakan strategi bagi pembelajaran sains di sekolah menengah karena dapat dilakukan secara luwes dan memenuhi kebutuhan nyata pengajar dan pembelajar. Model pembelajaran kooperatif tipe TGT merupakan model pembelajaran yang mengandung unsur permainan sehingga akan membuat siswa belajar dengan suasana yang menyenangkan sehingga materi yang diberikan akan mudah diserap dan diingat siswa.

Media pembelajaran adalah alat yang digunakan untuk mempermudah siswa memahami materi pelajaran. Media yang dapat digunakan dalam pembelajaran kimia adalah teka-teki silang. Pada penelitian ini, teka-teki silang yang dibuat berisi pertanyaanpertanyaan yang berhubungan dengan materi tata nama senyawa. Dalam pelaksanaannya, teka-teki silang melibatkan partisipasi peserta didik untuk aktif sejak kegiatan pembelajaran dimulai. Teka-teki silang berguna untuk meninjau ulang (review) materi-materi yang sudah disampaikan.

Game yang serius didasarkan pada teori pendidikan yang sehat seperti pembelajaran aktif atau bermasalah. Mereka dirancang untuk mengajar peserta dengan dimainkan sebanyak yang diperlukan dalam lingkungan yang tidak mengancam (Caufield, 2012).
Pembelajaran dengan situasi dan kondisi lingkungan yang mendukung, menjadikan siswa senang untuk belajar dan dengan mudah siswa menerima pelajaran. Berdasarkan studi penelitian, pembelajaran kimia untuk materi tata nama senyawa terkait dengan kaya akan konsep sehingga siswa sulit untuk memahaminya. Oleh karena itu, perlu dibuat strategi dan model pembelajaran yang lebih menarik sehingga siswa lebih mudah untuk memahami materi tata nama senyawa.

Kendala pembelajaran tersebut merupakan hasil wawancara terhadap 14 siswa dari kelas berbeda dengan jumlah siswa keseluruhan per kelas sebanyak 30 siswa. Dari wawancara diperoleh hasil belajar siswa yang rendah karena siswa kurang paham dengan konsep kimia yang dipelajari karena pembawaan guru ketika menjelaskan materi terlalu cepat, kurang memberikan motivasi kepada siswa, Pembelajaran di kelas belum bervariasi. Selain wawancara terhadap siswa, peneliti melakukan wawancara dengan guru kimia di SMA Swasta Parulian 1 Medan. Berdasarkan wawancara dengan guru kimia, materi kimia yang paling sulit dipahami oleh siswa adalah materi tata nama senyawa karena banyak konsep yang perlu dipahami. Materi tata nama senyawa meliputi aturan penamaan menurut IUPAC untuk senyawa anorganik dan senyawa organik. Banyaknya materi yang perlu dihafalkan terkadang membuat siswa enggan untuk belajar. Selain itu, proses pembelajaran yang didominasi oleh guru menyebabkan siswa kurang terlibat aktif dalam proses pembelajaran. Ketika pembelajaran berlangsung, kegiatan siswa hanya mendengarkan dan mencatat apa yang dituliskan oleh guru. Jarang ada siswa yang mengajukan maupun menanggapi pertanyaan guru. Hasil observasi peneliti di SMA Swasta Parulian 1 Medan, menunjukkan hasil belajar siswa-siswi masih tergolong rendah dengan kriteria ketuntasan minimal (KKM) yaitu 75 pada mata pelajaran kimia.

Terdapat beberapa hasil penelitian sebelumnya mengenai model pembelajaran kooperatif tipe TGT yang dapat meningkatkan hasil belajar siswa antara lain, yaitu penelitian Safitri, dkk., (2018) mengemukakan Hasil 

Siswa Pada Materi Tata Nama Senyawa di SMA Swasta Parulian I

penelitian menunjukkan bahwa: (1) Model pembelajaran kooperatif tipe teams game tournament berpengaruh terhadap motivasi siswa sebesar 96,64\%; (2) Terdapat perbedaan motivasi belajar siswa yang diajarkan dengan teams game tournament berbantuan media teka-teki silang dan metode ceramah pada materi Koloid. Dari hasil penelitian (Apriantiy, 2017) menunjukkan bahwa nilai rata-rata pre-test yaitu 44,67 nilai rata-rata post-test yaitu 81,67 dan nilai N-Gain sebesar 0,7 dengan kategori sedang. Berdasarkan hasil penelitian dapat disimpulkan bahwa pembelajaran kimia dengan model pembelajaran teams game tournament dapat meningkatkan hasil belajar siswa pada materi tata nama senyawa kimia di MAS Darul Ihsan Aceh Besar. Penelitian dari (Abdillah, dkk, 2018) Hasil analisis data mengungkapkan bahwa skor pretes rata-rata adalah 36 dan postes adalah 62,94. Selain itu, analisis statistik uji-t menunjukkan nilai signifikansi $0,00(0,00<0,05)$ yang berarti bahwa ada perbedaan dalam hasil belajar siswa antara sebelum dan sesudah model pembelajaran TGT berbasis kartu pertanyaan dilaksanakan. Dari hasil penelitian (Yunus, dkk 2017) Nilai rata-rata kelas eksperimen I dan eksperimen II masing-masing sebesar 87,83 dan 79,3 dengan standar deviasi masing-masing secara berturutturut 8,31 dan 10,26. Persentase ketuntasan untuk masing-masing kelas eksperimen I dan kelas eksperimen II yaitu $80 \%$ dan $60 \%$. Data tidak terdistribusi normal dan bersifat homogen. Pengujian hipotesis dilakukan dengan uji mann-whitney (U-Test) menghasilkan $Z_{\text {hitung }}>Z_{\text {tabel }}=2,59>1,64$ pada $=0,05$. Disimpulkan bahwa ada perbedaan hasil belajar siswa yang diajar menggunakan model pembelajaran "Teams Games Tournament. Berdasarkan penelitian dari Mutia Nasutian yang tertuang dalam jurnal internasional yang berjudul " The Effect of Team Games Tournament (TGT) Method Toward Vocabulary Mastery at the Tenth Grade Students of High School 1 Padangsidimpuan" hasil yang diperoleh ialah Prestasi siswa dalam penguasaan kosakata dengan menggunakan Metode TGT dikategorikan "baik". Prestasi siswa dalam penguasaan kosakata dengan menggunakan Metode Konvensional dikategorikan "cukup". Ada pengaruh yang signifikan dari Metode TGT terhadap penguasaan kosakata pada siswa kelas tujuh SMA Negeri 1 Padangsidimpuan. Hal ini dapat dilihat dari perhitungan bahwa skor ttest lebih tinggi dari ttabel $(2,68>2,00)$.

Berdasarkan latar belakang masalah yang telah diuraikan di atas, maka peneliti tertarik untuk membahas dan mengangkat masalah tersebut menjadi sebuah judul penelitian, yaitu "Pengaruh Model Pembelajaran Kooperatif Team Games Tournament (TGT) Dengan Berbantuan Media Teka - Teki Silang (TTS) Terhadap Hasil Belajar Dan Motivasi Siswa Pada Materi Tata Nama Senyawa Di Kelas X SMA Swasta Parulian 1 Medan"

\section{METODE}

Penelitian ini telah di laksanakan di SMA Swasta Parulian 1 Medan yang beralamat di Jl. Stadion No. 23 Medan Sumut. Waktu penelitian akan dilakukan pada bulan Maret sampai dengan bulan Mei Tahun Ajaran 2018/2019. Populasi dalam penelitian ini adalah seluruh siswa kelas X SMA Swasta Parulian 1 Medan Tahun ajaran 2018/2019 berjumlah 2 kelas sampel pada penelitian ini di gunakan 2 kelas dengan jumlah 60 siswa.

Teknik pengambilan sampel yang digunakan dalam penelitian yaitu teknik purposive sampling. Teknik purposive sampling adalah metode yang menggunakan kriteria yang telah di pilih oleh peneliti dalam memilih sampel. Penelitian ini menggunakan dua kelas, yaitu satu kelas eksperimen dan satu kelas kontrol. Dalam penelitian ini untuk memperoleh data digunakan instrument test dalam bentuk tes objektif dan instrumen non test dalam bentuk angket. Sebelum digunakan, instrumen test terlebih dahulu diuji dengan uji validasi, tingkat kesukaran soal, daya pembeda soal, dan uji reabilitas tes.

Pendekatan yang digunakan dalam penelitian ini adalah pendekatan kuantitatif karena data yang disajikan berhubungan dengan angka-angka, dan teknik analisis data yang digunakan adalah teknik analisis statistik. Jenis penelitian ini adalah true 
experimental dengan menggunakan pretestposttest control group design, yaitu penelitian dengan pretest maupun posttest antara kelas eksperimen dan kontrol.

Setelah diperoleh data hasil penelitian maka selanjutnya data akan diuji normalitasnya yang berfungsi untuk membedakan data statistik yang akan dianalisis terdistribusi normal atau tidak. Dalam penelitian ini yang digunakan adalah uji Chi-Kuadrat. Dan kemudian diuji Homogenitasnya dengan menggunakan uji homogenitas atau uji kesamaan varians dengan kriteria jika $\mathrm{F}_{\text {tabel }}<\mathrm{F}_{\text {hitung }}$ maka data memiliki varians yang homogen. Setelah dilakukan pengujian normalitas dan homogenitas data dan apabila diperoleh data tersebut berdistribusi normal dan homogen maka uji hipotesis dapat menggunakan analisis statistik parametrik.

Uji hipotesis digunakan uji-t (uji pihak kanan), kriteria pengujian jika $t_{\text {hitung }}>t_{\text {tabel }}$ dengan taraf signifikansi $\alpha=0,05$ dan $\mathrm{d}_{\mathrm{k}}=\mathrm{n}_{1}+$ $\mathrm{n}_{2}-2$. Kemudian dihitung persen $(\%)$ peningkatan hasil belajar dananalisis data instrumen non-tes. Teknik analisis terhadap data hasil angket motivasi belajar menggunakan skala sikap (Attitude scale). Bentuk dari skala sikap dalam pertemuan ini menggunakan skala likert.

\section{HASIL DAN PEMBAHASAN}

Berdasarkan data nilai hasil belajar siswa yang diperoleh pada penelitian ini dan setelah data ditabulasikan maka diperoleh rata-rata, standar deviasi, dan varians dari data preetest dan posttest dari kelas kontrol dan kelas eksperimen seperti pada tabel dibawah ini:

Tabel 1. rata-rata, standar deviasi, dan varians data preetest dan posttest

\begin{tabular}{ccccccc}
\hline Kelas & \multicolumn{2}{c}{ Nilai rata- } & \multicolumn{2}{c}{$\mathrm{S}$} & \multicolumn{2}{c}{$\mathrm{S}^{2}$} \\
\cline { 2 - 7 } & \multicolumn{2}{c}{ rata } & & & & \\
\cline { 2 - 7 } & Pree & Post & Pree & Post & Pree & Post \\
test & test & test & test & test & test \\
\hline Kontro & 33,1 & 75 & 6,08 & 8,88 & 37,0 & 36,2 \\
1 & 6 & & & & 4 & 0 \\
Eksper & 32,1 & 81,6 & 5,76 & 9,17 & 33,2 & 38,5 \\
imen & 6 & 6 & & & 7 & 0 \\
\hline
\end{tabular}

Berdasarkan tabel 1. maka dapat digambarkan perolehan rata-rata nilai preetest dan nilai posttest pada kelas kontrol dan kelas eksperimen pada gambar 1. berikut:

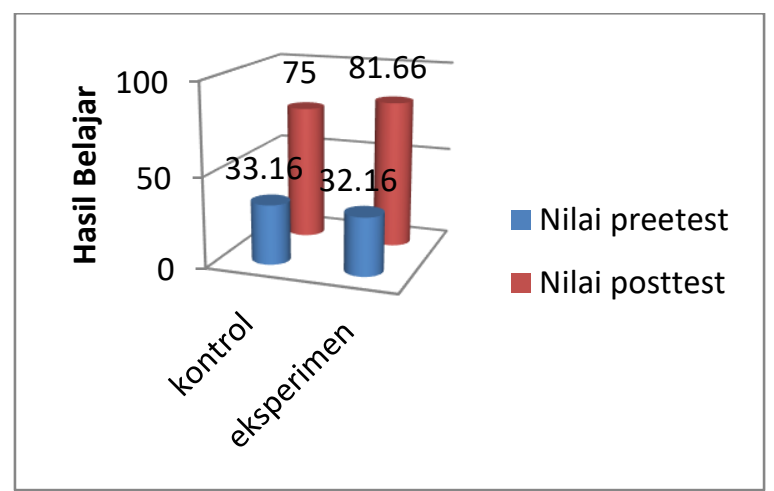

Gambar 1. Diagram Nilai Rata-Rata Preetest Dan Posttest Siswa Kelas Kontrol Dan Kelas Eksperimen

Hasil Belajar

Uji hipotesis dilakukan untuk mengetahui apakah hipotesis alternatif (Ha) diterima atau ditolak. Hipotesis penelitian diuji dengan uji satu pihak (uji pihak kanan). Uji hipotesis dilakukan pada taraf signifikan $\alpha=0,05$ dengan kriterial pengujian jika $t_{\text {hiting }}>t_{\text {tabel }}$ maka hipotesis alternatif $(\mathrm{Ha})$ diterima dan hipotesis nol (Ho) ditolak. Data hasil perhitungan uji hipotesis dapat dilihat pada tabel 2 berikut ini:

Tabel 2. Uji Hipotesis Penelitian

\begin{tabular}{|c|c|c|c|c|c|c|}
\hline $\begin{array}{l}\text { Sumb } \\
\text { er data }\end{array}$ & Data & $\bar{X}$ & $S^{2}$ & $\begin{array}{l}t_{\text {hit }} \\
\text { ung }\end{array}$ & $\begin{array}{l}\mathrm{T}_{\mathrm{t}} \\
\text { abe }\end{array}$ & $\begin{array}{l}\text { Keter } \\
\text { angan }\end{array}$ \\
\hline $\begin{array}{l}\text { Penin } \\
\text { gkatan }\end{array}$ & $\begin{array}{l}\text { Kontro } \\
1\end{array}$ & $\begin{array}{l}76, \\
33\end{array}$ & $\begin{array}{l}36, \\
20\end{array}$ & $\begin{array}{l}3, \\
29\end{array}$ & $\begin{array}{l}1, \\
67\end{array}$ & $\begin{array}{l}\mathrm{Ha} \\
\text { diteri }\end{array}$ \\
\hline $\begin{array}{l}\text { hasil } \\
\text { belajar } \\
\text { (gain) }\end{array}$ & $\begin{array}{l}\text { Ekspe } \\
\text { rimen }\end{array}$ & $\begin{array}{l}81, \\
33\end{array}$ & $\begin{array}{l}38, \\
50\end{array}$ & & & $\begin{array}{l}\text { ma, } \\
\text { Ho } \\
\text { ditola } \\
\text { k }\end{array}$ \\
\hline
\end{tabular}

Berdasarkan tabel 2 diperoleh harga $t_{\text {hiting }}>$ $t_{\text {tabel }}$ yaitu 3,29 $>1,67$ dan taraf signifikan $(\alpha=$ $0,05)$ sehingga Ha diterima yang berarti hasil belajar siswa yang mendapatkan pembelajarna dengan model pembelajaran kooperatifTeam Games Tournament(TGT) berbantuan media teka - teki silang lebih tinggi dari hasil belajar siswa yang mendapatkan pembelajaran dengan model konvesional.

Peningkatan Hasil Belajar (Gain)

Untuk melihat peningkatan hasil belajar kimia siswa kelas kontrol dan kelas eksperimen dilihat dari rata - rata gain 

Siswa Pada Materi Tata Nama Senyawa di SMA Swasta Parulian 1

ternormalsasi kelas kontrol dan kelas eksperimen. Data hasil perhitungan peningkatan hasil belajar (gain) dapat dilihat pada tabel 4. berikut ini:

\begin{tabular}{cccc}
\multicolumn{3}{c}{ Tabel 4. Peningkatan Hasil Belajar } \\
\hline Kelas & Kriteria & $\begin{array}{c}\text { Rata- } \\
\text { Tara } \\
\text { Gain }\end{array}$ & $\begin{array}{c}\text { \%Peningkatan } \\
\text { Hasil Belajar } \\
\text { (Gain) }\end{array}$ \\
\hline Kontrol & $\mathrm{G}<0,3$ & 0,6256 & $62,56 \%$ \\
& $=$ rendah & & \\
& $0,3 \leq \mathrm{g} \geq$ & & \\
& $0,7=$ & & \\
Eksperimen & sedang & 0,7246 & $72,46 \%$ \\
& $\mathrm{G}>0,7$ & & \\
\hline & $=$ tinggi & & \\
\hline
\end{tabular}

Berdasarkan tabel 4 diiperoleh hasil peningkatan hasil belajar siswa pada kelas eksperimen 72,46 \% lebih tinggi dari pada peningkatan hasil belajar pada kelas kontrol sebesar $62,56 \%$. Jadi, perbedaan peningkatan hasil belajar siswa pada kelas eksperimen dengan kelas kontrol adalah 9,9\%.

Analisis Data Instrumen Non - Tes

Hasil perhitungan motivasi siswa awal berdasarkan skala likers menunjukan jumlah skor motivasi awal sebesar 86,9, sedangkan pada motivasi siswa akhir menunjukan jumlah sebesar 96. Berdasarkan hal diatas menunjukan bahwa motivasi akhir siswa lebih tinggi dari pada motivasi awal.

Tabel 5. Rata-Rata Nilai Angket Motivasi

\begin{tabular}{ccc}
\hline Ranah & $\begin{array}{c}\text { Kelas } \\
\text { eksperimen }\end{array}$ & Rata-rata \\
\hline \multirow{3}{*}{ Motivasi } & $\begin{array}{c}\text { Motivasi } \\
\text { Awal } \\
\text { Motivasi } \\
\text { Akhir }\end{array}$ & 86,9 \\
& 96 \\
\hline
\end{tabular}

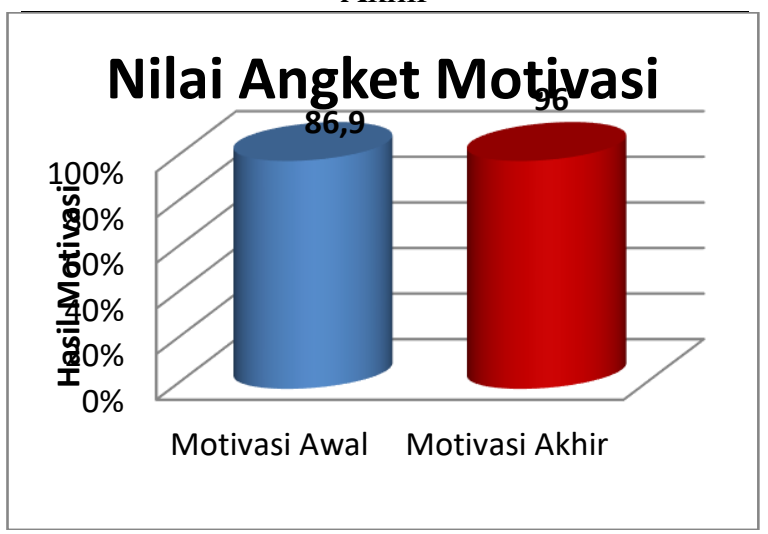

Gambar 2. Diagram Nilai Rata-Rata Angket Motivasi Awal Dan Akhir Siswa Kelas Eksperimen
KESIMPULAN

Berdasarkan hasil penelitian yang telah dilakukan maka dapat diambil kesimpulan yaitu :

1. Hasil belajar siswa yang mendapatkan pembelajaran dengan model kooperatif Team Games Tournament(TGT) berbantuan media teka - teki silang pada materi tata nama senyawa di kelas eksperimen adalah 81,66 sedangkan ketuntasan pada pelajaran kimia adalah 75 lebih tinggi dari hasil belajar siswa yang mendapatkan pembelajaran dengan metode konvesional.

2. Motivasi akhir belajar siswa dengan menggunakan model pembelajaran kooperatif Team Games Tournament(TGT) berbantuan media teka - teki silang terhadap materi tata nama senyawa kimia adalah 96 sedangkan pada motivasi awal sebesar 86,8.

3. model pembelajaran kooperatif Team Games Tournament (TGT) berbantuan media teka-teki silang memiliki pengaruh yang signifikan terhadap peningkatan hasil belajar siswa pada materi tata nama senyawa kimia.

4. model pembelajaran kooperatif Team Games Tournamnet (TGT)berbantuan media teka-teki silang memiliki pengaruh yang signifikan dalam meningkatkan motivasi belajar siswa pada tata nama senyawa kimia.

5. Motivasi memberikan kontribusi yang positif terhadap hasil belajar siswa dengan model pembelajaran kooperatif Team Games Taournament (TGT) berbantuan media teka - teki silang.

\section{DAFTAR PUSTAKA}

Abdillah, Z., Fadhilah, R., \& Rizmahardian A.K. (2018). Efektivitas Model Pembelajaran Kooperatif Tipe Teams Games Tournament (TGT) Berbantuan Media Kartu Soal Pada Sub Materi Ikatan Kovalen Kelas X Mia Di Sma Islam Haruniyah Pontianak. Jurnal Ilmiah, 6: 1826

Ahmad, Z., dan Mahmood, N. (2010). Effects of Cooperative Learning vs. Traditional 
Instruction on Prospective Teachers ${ }^{\text {ee }}$ Learning Experience and Achievement. Journal of Faculty of Educational Sciences, 45: 151-164.

Aprianty, dan Helvy. (2017). Pengaruh Model Pembelajaran TGT Terhadap Hasil Belajar Siswa pada Materi Tata Nama Senyawa di MAS Darul Ihsan Aceh Besar. Prosiding Seminar MIPA III, ISBN 978-602-509390-6. 129-134.

Cauflied, C. (2012). Shall We Play a Game Modern Applied Science. 6, (1),2-16.

Safitri, S., Kurniawan, R.A., dan Fahillah, R. (2018). Pengaruh Pembelajaran Kooperatif Tipe Team Game Tournament berbantuan Media Teka Teki Silang terhadap Motivasi Siswa pada Materi Koloid. Jurnal Pendidikan, 16: 20-34.

Soebagio. (2000). Penggunaan Pembelajaran Kooperatif Tipe Team Tames Tournament Untuk Peningkatan Kualitas Pembelajaran Konsep Larutan Asam-Basa, Jakarta : PPGSM.

Veloo, A., dan Sitie Chairhany. (2013). Fostering students' attitudes and achievement in probability using teamsgames-tournaments. Procedia - Social and Behavioral Sciences 93 ( 2013 ) : 59 64.

Yunus, N.W., Anwar, M., dan Alimin. (2017). Perbedaan Hasil Belajar Siswa yang Diajar Menggunakan Model Pembelajaran Teams Games Tournaments (TGT) dengan Model Pembelajaran Konvensional Di Kelas Xi Mia SMA Negeri 2 Pangkajene (Studi pada Materi Pokok Asam Basa). Jurnal Chemica, $18: 56-63$. 